\title{
Regulation of protein phosphorylation in the cyanobacterium Anabaena strain PCC 7120
}

\author{
Nicholas H. Mann, ${ }^{*} \uparrow$ Rosmarie RippKa and Michael Herdman \\ Unité de Physiologie Microbienne, CNRS URA 1129, Département de Biochimie et Génétique Moléculaire, Institut \\ Pasteur, 28 rue du Dr Roux, F-75724 Paris Cedex 15, France
}

(Received 27 June 1990; revised 17 September 1990; accepted 19 October 1990)

\begin{abstract}
Protein kinase activities have been detected in cell-free extracts of the cyanobacterium Anabaena PCC 7120. At least 12 polypeptides in the soluble fraction were phosphorylated in vitro at the expense of $\left[\gamma-{ }^{32} \mathrm{P} \mid \mathrm{ATP}\right.$ and the pattern of phosphorylation was shown to be regulated by intermediary metabolites and other effectors, at physiological concentrations. Glucose 6-phosphate exerted a regulatory effect on a phosphopolypeptide of $M_{\mathrm{r}}$ 56000 (p56) by stimulating a protein phosphatase, whereas ribulose 5-phosphate inhibited the corresponding protein kinase. In addition, DTT and the calmodulin antagonist trifluoperazine influenced the phosphorylation state of several different polypeptides, indicative of control by redox conditions and a calmodulin-like mediator, respectively. Furthermore, it was established that the phosphorylation of p56 required $\mathrm{Mg}^{2+}(>100 \mu \mathrm{M})$ whereas that of a polypeptide of $M_{\mathrm{r}} \mathbf{1 6 0 0 0}$ occurred in the absence of $\mathrm{Mg}^{2+}$ and was inhibited by high concentrations ( $>1 \mathrm{mM}$ ) of this cation. Several of the phosphopolypeptides detected in vitro corresponded in mobility on SDSPAGE to species phosphorylated in vivo.
\end{abstract}

\section{Introduction}

It is becoming increasingly clear that protein phosphorylation plays an important role in the control of bacterial metabolism (see Cozzone, 1988; Stock et al., 1989). This form of post-translational modification of proteins provides a mechanism by which organisms can respond rapidly to changes in their internal and external environments over timescales which would preclude a transcriptional response. Protein phosphorylation may also provide a mechanism by which transcription may be modulated in response to such environmental alterations. Protein phosphorylation may involve three different types of covalent bonds with phosphate groups. The hydroxylated amino acids produce monoesters, whereas basic and acidic amino acids form phosphoramidates and acyl phosphates, respectively. Initially, studies on protein phosphorylation in bacteria tended to concentrate on proteins which were phosphorylated via a monoester linkage since it was thought that proteins containing phosphoramidates or acyl phosphates might

† Permanent address: Department of Biological Sciences, University of Warwick, Coventry CV4 7AL, UK.

Abbreviations: Fru-6-P, fructose 6-phosphate; Fru-1,6- $\mathrm{P}_{2}$, fructose 1,6-bisphosphate; Glc-6-P, glucose 6-phosphate; Ru-5-P, ribulose 5phosphate. represent enzymic intermediates. However, it has been recently established that there is a highly conserved and widely distributed family of proteins which constitute two-component systems involved in signal transduction and that phosphoramidates and acyl phosphates are the phosphate linkages found in these systems (see Stock $e t$ al., 1989).

In cyanobacteria, the primary nutritional mode is photoautotrophy, though many species are capable of photoheterotrophic growth at the expense of organic substrates such as glucose or fructose, and some are also capable of chemoheterotrophic growth at the expense of these carbon sources (see Smith, 1982). In addition, when cyanobacteria are transferred from photoautotrophic conditions into the dark they utilize glucose, derived from storage polysaccharides, via the oxidative pentose phosphate pathway (see Smith, 1982). It is likely that such metabolic transitions involve rapid modulation of some enzyme activities via post-translational mechanisms prior to a more general (and slower) transcriptional response. Although it has been well established that a number of enzymes involved in carbon, nitrogen and sulphur metabolism in cyanobacteria are subject to regulation by thioredoxins, and may be activated or inactivated depending on the redox state of these modulators (see Rowell et al., 1988; Crawford et al., 
1988), it is possible that the activity of other enzymes may be controlled by protein phosphorylation. Protein phosphorylation has been demonstrated in only two cyanobacterial species, Fremyella diplosiphon PCC 7601 (Schuster et al., 1984) and Synechococcus PCC 6301 (Allen et al., 1985; Sanders et al., 1989) and is thought to play a regulatory role in the chromatic acclimation (photosystem stoichiometry adjustment) of Synechococcus PCC 6301 in response to changes in the spectral quality of light.

One approach to the study of protein phosphorylation is to analyse protein kinase activities in cell-free extracts in conjunction with analyses of the resulting phosphopolypeptide profiles on SDS-PAGE. The addition of key metabolites or other potential effectors to such in vitro assays may reveal differential enhancement or inhibition of phosphorylation among specific polypeptide species (Londesborough, 1986). Therefore, in vitro kinase studies may help to recognize metabolic pathways in which protein phosphorylation is involved as a regulatory mechanism and to ultimately identify and characterize the individual components comprising such systems. It is important, however, to establish that the patterns of phosphorylation in vitro resemble those obtained in vivo. We have used both approaches to analyse protein phosphorylation in the filamentous heterocystous $\mathrm{N}_{2^{-}}$ fixing cyanobacterium Anabaena PCC 7120, as a preliminary step in establishing the role of protein phosphorylation as a regulatory mechanism in this photoautotrophic organism.

\section{Methods}

Organism and growth. The strain under study was Anabaena PCC 7120 (Rippka et al., 1979) which, according to DNA/DNA hybridization studies by Lachance (1981), should be assigned to the genus Nostoc. This strain is available from the Culture Collection of Cyanobacteria at the Institut Pasteur, Paris, France.

For the phosphorylation studies, a single-colony isolate (WTg1) was made from a stock culture of Anabaena PCC 7120 to ensure homogeneity of the cell population.

For the preparation of extracts, Erlenmeyer flasks (1 l) containing $500 \mathrm{ml}$ of medium BG $1 \mathrm{I}_{0}$ (Rippka et al., 1979) and filter-sterilized $\mathrm{NaHCO}_{3}(10 \mathrm{~mm})$ were inoculated to an initial $\mathrm{OD}_{750}$ of 0.03 (measured in a Kontron Uvikon model 860 spectrophotometer). If desired, this medium was supplemented with glucose ( $50 \mathrm{~mm}), \mathrm{NaNO}_{3}$ $(10 \mathrm{~mm})$ or both. Glucose had no effect on the growth rate under lightsaturating conditions but slightly enhanced the growth yield once light became limiting. The cultures were agitated with magnetic stirring bars and were gassed with air/ $\mathrm{CO}_{2}(99: 1, \mathrm{v} / \mathrm{v})$ introduced above the surface of the culture via cotton plugs equipped with sterile Pasteur pipettes (Rippka et al., 1981). Light was supplied continuously by a ramp of three fluorescent lamps (Mazdafluor, Blanc Industrie) providing a photon flux density of $50 \mu \mathrm{mol} \mathrm{m} \mathrm{m}^{-2} \mathrm{~s}^{-1}$ at the surface of the culture vessels. Under these conditions the doubling times of the cultures during exponential growth (up to an $\mathrm{OD}_{750}$ of $0.7-0.8$ ) were about 20 $24 \mathrm{~h}$, irrespective of the medium employed.

The purity of the cultures was verified as described by Rippka et al. (1979).
Cultures were harvested by centrifugation $\left(20 \mathrm{~min}, 10000 \mathrm{~g}, 4^{\circ} \mathrm{C}\right)$ at the end of exponential growth (at an $\mathrm{OD}_{750}$ of $0 \cdot 8-1 \cdot 2$, equivalent to a total protein content of $120-180 \mu \mathrm{g} \mathrm{ml}^{-1}$ ) and the volumes were adjusted to give pellets of $15-20 \mathrm{mg}$ total protein (determined by the Lowry method). After one wash $(20 \mathrm{ml})$ in the buffer of choice $[50 \mathrm{~mm}$ HEPES/ $\mathrm{NaOH}, \mathrm{pH} 7.5$, containing $20 \mathrm{~mm}-\mathrm{MgCl}_{2}$ (HM buffer) or $50 \mathrm{mM}$ Tris/maleate, $\mathrm{pH} 7.5$ (TM buffer)], the pellets were either frozen at $-70{ }^{\circ} \mathrm{C}$ or used immediately for the preparation of extracts.

Preparation of extracts. All steps in the preparation of extracts, including harvesting of the cells, were performed at $4{ }^{\circ} \mathrm{C}$, and the buffers, glassware and other equipment were sterilized by filtration or by autoclaving, as appropriate.

The cell pellets (see above) were resuspended in HM or TM buffer $(5 \mathrm{ml})$ and transferred into Corex centrifuge tubes $(15 \mathrm{ml})$ containing $3 \mathrm{~g}$ sterile glass beads $(0.11 \mathrm{~mm}$ diameter, Braun). The tubes were closed with rubber sleeves and were vortexed for 4-12 min (see below) on a vortex mixer (Cenco Instrumenten, Breda, The Netherlands) at maximum speed with cycles of $2 \mathrm{~min}$ and intermittent cooling ( $2 \mathrm{~min}$ ) on ice. The beads were then allowed to settle and the broken cell suspensions were transferred to clean Corex tubes. The beads were washed with $1 \mathrm{ml}$ of the appropriate buffer and the washing suspension pooled with the corresponding broken cell suspension.

The degree of cell breakage was estimated by microscopic examination of these crude extracts, in conjunction with measurements of the phycobiliprotein content of the supernatants produced after precipitation of membrane fragments with streptomycin sulphate (Tandeau de Marsac \& Houmard, 1988). The short (4 min) glass bead treatments used for the experiments shown in Figs $1(a)$ and $1(b)$ were sufficient to break about $75 \%$ of the vegetative cells but did not result in a significant degree of heterocyst breakage. In order to ensure efficient breakage of both cell types, the glass bead treatment was extended to a total of 8-12 min for the experiments shown in Figs 2-4.

The soluble fractions of extracts $(5 \mathrm{ml})$ were obtained by two successive centrifugations $(15 \mathrm{~min}, 1000 \mathrm{~g}$ followed by $30 \mathrm{~min}$, $60000 \mathrm{~g}$ ). For particulate fractions the pellets of the $60000 \mathrm{~g}$ centrifugation were washed in the same volume $(5 \mathrm{ml})$ of fresh buffer and recentrifuged $(30 \mathrm{~min}, 60000 \mathrm{~g}$ ) before being finally resuspended in $2.5 \mathrm{ml}$ of buffer containing $0 \cdot 1 \%$ Triton X-100.

For comparative analyses of extracts from cells grown under different culture conditions the protein contents were normalized by dilution after protein determination by the method of Bradford (1976) using the Bio-Rad protein assay reagent.

Protein kinase assay. Samples ( $10 \mu \mathrm{l}$, containing 10-20 $\mu \mathrm{g}$ protein) of cell-free extracts were incubated at room temperature with $185 \mathrm{kBq}$ $(5 \mu \mathrm{Ci})$ of $\left[\gamma^{-32} \mathrm{P}\right] \mathrm{ATP}$ (Amersham, $110 \mathrm{TBq} \mathrm{mmol}^{-1}$ ), appropriately diluted in sterile $\mathrm{H}_{2} \mathrm{O}$, in a total reaction volume of $20 \mu \mathrm{l}$ and at a final concentration of $83 \mathrm{nM}$. The addition of unlabelled ATP (up to $10 \mu \mathrm{M}$ ) altered neither the pattern of protein phosphorylation nor the intensity of labelling. Since preliminary time-course experiments indicated that the kinase reactions were linear over the course of $1 \mathrm{~h}$, all experiments (unless otherwise stated) were performed for this period in the absence of added unlabelled ATP. Intermediary metabolites and other effectors were dissolved in $\mathrm{H}_{2} \mathrm{O}$ and added to the kinase reaction at a final concentration of $1 \mathrm{mM}$, unless otherwise stated. Reactions were terminated by the addition of an equal volume of double-strength denaturation buffer (Laemmli, 1970) and boiling for $4 \mathrm{~min}$. Membrane fractions assayed for kinase activity were centrifuged $(2 \mathrm{~min}, 12000 \mathrm{~g}$ ) after denaturation to remove insoluble material. The entire sample was loaded onto the gel for analysis by SDS-PAGE.

In vivo labelling. For in vivo labelling with $\left[{ }^{32} \mathrm{P}\right]$ orthophosphate, the growth conditions were similar to those described for the preparation of extracts, except that the culture volumes were reduced to $50 \mathrm{ml}$, contained in Erlenmeyer flasks $(150 \mathrm{ml})$ fitted with side arms. Light 
was provided by a ramp of three fluorescent tubes (Claude 13W/B1) yielding a photon flux density of $50-60 \mu \mathrm{mol} \mathrm{m}^{-2} \mathrm{~s}^{-1}$ at the surface of the culture vessels. Growth was monitored with a Corning colorimeter (580 $\mathrm{nm}$ filter) allowing measurements directly on the side arms of the vessels. From the $\mathrm{OD}_{750}$ (Kontron)/OD $\mathrm{OD}_{580}$ (Corning) ratio, the protein content of the cultures was estimated on the basis of the relationship: $\mathrm{OD}_{750}$ of $1 \equiv 150 \mu \mathrm{g}$ protein $\mathrm{ml}^{-1}$. At an $\mathrm{OD}_{750}$ of $0 \cdot 2-0 \cdot 3$ the cultures were supplemented with $\left[{ }^{32} \mathrm{P}\right]$ orthophosphate (Amersham, $370 \mathrm{MBq} \mathrm{ml}^{-1}$, acid-free, carrier-free) to a final activity of $740 \mathrm{kBq}$ $(20 \mu \mathrm{Ci}) \mathrm{ml}^{-1}$ by means of a sterile disposable syringe. After further incubation for $24 \mathrm{~h}$, the cultures were harvested $(15 \mathrm{~min}, 1000 \mathrm{~g})$, washed in $6 \mathrm{ml}$ HEPES/NaOH buffer $(50 \mathrm{~mm}, \mathrm{pH} \mathrm{7.5)}$ and recentrifuged $(5 \mathrm{~min}, 1000 \mathrm{~g})$. The resulting pellets were resuspended in $1.5 \mathrm{ml}$ of the same buffer and half of this cell suspension was frozen $\left(-20^{\circ} \mathrm{C}\right)$ in Corex tubes $(15 \mathrm{ml})$ with no further treatment. The remainder was stored as a pellet at $-20^{\circ} \mathrm{C}$ after centrifugation $(2 \mathrm{~min}, 12000 \mathrm{~g})$ in an Eppendorf microfuge. The total protein content of each sample was $2-2.5 \mathrm{mg}$.

Samples stored as pellets were resuspended in $800 \mu$ l single-strength denaturation buffer (Laemmli, 1970) and heated for $4 \mathrm{~min}$ at $100^{\circ} \mathrm{C}$. Cell debris and other insoluble materials were removed by centrifugation in an Eppendorf microfuge $(2 \mathrm{~min}, 12000 \mathrm{~g}$ ) and the supernatants were refrozen $\left(-20^{\circ} \mathrm{C}\right)$. Samples stored as cell suspensions $(750 \mu \mathrm{l})$ in Corex tubes were supplemented with $1.75 \mathrm{ml} \mathrm{HEPES} / \mathrm{NaOH}$ buffer $(50 \mathrm{mM}, \mathrm{pH} 7.5)$ and $1.5 \mathrm{~g}$ sterile glass beads. After $4 \times 2$ min breakage by vortexing (see above), $\mathrm{MgCl}_{2}$ was added to a final concentration of $1 \mathrm{mM}$ together with DNAase I and RNAase A, both at a final concentration of $10 \mu \mathrm{g} \mathrm{ml}^{-1}$. After incubation (30 min at room temperature) the extracts were centrifuged $(5 \mathrm{~min}, 1000 \mathrm{~g}$ ) to remove large cell debris and the supernatants were frozen $\left(-20^{\circ} \mathrm{C}\right)$ as small samples $(500 \mu l)$ until required.

For SDS-PAGE the extracts $(20 \mu \mathrm{l})$ prepared by glass bead treatment were incubated at $100{ }^{\circ} \mathrm{C}$ for $4 \mathrm{~min}$ after addition of an equal volume of double-strength denaturation buffer (Laemmli, 1970) and the entire samples (containing equal protein loadings of about $20 \mu \mathrm{g}$ ) were applied onto the gel.

$S D S-P A G E$ and autoradiography. Exponential gradient polyacrylamide $(10-30 \%, w / v)$ gels were prepared and run as described by Turner \& Mann (1986) and silver stained by the method of Wray $e t$ al. (1981) prior to drying and autoradiography at $-70^{\circ} \mathrm{C}$ with a Dupont Cronex Lightning Plus intensifying screen. The pattern of labelled polypeptides was highly reproducible for control samples, although the migration and resolution varied slightly in different experiments. Metabolites and other compounds that significantly influenced the pattern of phosphorylation were tested for their effects at least two or three times. SDS-PAGE gels containing samples which had been labelled in vivo were treated for $60 \mathrm{~min}$ at $78^{\circ} \mathrm{C}$ in $16 \%(\mathrm{w} / \mathrm{v})$ trichloroacetic acid, washed as described by Manai \& Cozzone (1982) and stained with Coomassie Brilliant Blue R250 prior to drying and autoradiography.

Phosphoamino acid analysis. Following in vitro labelling of proteins and subsequent SDS-PAGE the polypeptides were transferred to an Immobilon-P membrane (Millipore) by Western blotting. The membrane was air dried and subjected to autoradiography. Regions of the membrane corresponding to labelled polypeptides of interest were cut out and incubated in Eppendorf tubes with $300 \mu \mathrm{HCl}(6 \mathrm{M})$ at $110^{\circ} \mathrm{C}$ for $2 \mathrm{~h}$. The membrane was then removed from the tube and the remaining hydrolysate was freeze-dried. Phosphoamino acids in the protein hydrolysate were then identified as described by Turner \& Mann (1986) using the $O$-phosphorylated derivatives of serine, threonine and tyrosine as standards.

Activity of glucose-6-phosphate dehydrogenase (EC 1.1.1.49). Extracts were prepared in TM buffer and assayed for Glc-6-P dehydrogenase activity as described by Schaeffer \& Stanier (1978).
Chemicals. All intermediary metabolites employed, together with ATP, cAMP, cGMP, dithiothreitol, trifluoperazine, HEPES, streptomycin sulphate, deoxyribonuclease $I$, ribonuclease $A$ and phosphoamino acids were obtained from Sigma. Glutathione (oxidized and reduced) was from Serva. Acrylamide and bisacrylamide (Electran grade) were from BDH and SDS from Serlabo. Protein standards for $M_{\mathrm{r}}$ estimations were obtained from Pharmacia. The protein assay reagent was obtained from Bio-Rad and radiochemicals from Amersham. All other chemicals were of the highest purity commercially available.

\section{Results and Discussion}

\section{Influence of key intermediary metabolites and other effectors on protein phosphorylation in vitro}

To establish whether protein kinase activities were detectable in vitro, a cell-free extract of Anabaena PCC 7120 was made in $\mathrm{HM}$ buffer from cells grown under $\mathrm{N}_{2}-$ fixing conditions in the presence of glucose. The extract was separated into soluble and particulate fractions which were then assayed for protein kinase activities. Key intermediary metabolites and other potential effectors, all at concentrations of $1 \mathrm{~mm}$, were added to establish whether they exerted any effect on the profile of phosphorylated polypeptides. It is clear that at least twelve polypeptides in the soluble fraction became phosphorylated under these conditions (Fig. 1a). Several of the effectors tested had a significant influence on the pattern.

DTT stimulated the phosphorylaton of three polypeptides of $M_{\mathrm{r}} 83000,78000$ and 34000 (Fig. 1 a). It seems likely that this modulation of kinase/phosphatase activities in response to DTT could be mediated via thioredoxins, which have been demonstrated to control the activities of a variety of enzymes in cyanobacteria (see Rowell et al., 1988; Crawford et al., 1988).

Fructose 6-phosphate (Fru-6-P) and fructose 1,6bisphosphate (Fru-1,6- $\mathrm{P}_{2}$ ) markedly reduced the incorporation of label into a polypeptide of $M_{\mathrm{r}} 56000$ (p56) while having no effect on the incorporation into other phosphopolypeptides (Fig. 1a). A similar experiment (Fig. 1b) with additional effectors showed that glucose 6phosphate (Glc-6-P) and ribulose 5-phosphate (Ru-5-P) also markedly reduced incorporation into the p56 polypeptide. Protein phosphorylation was not affected by cyclic nucleotides, in agreement with observations made with other bacteria (Skorko, 1984; Dadssi \& Cozzone, 1985; Holuigue et al., 1985; Londesborough, 1986).

The differential action of trifluoperazine (TFP), which inhibited phosphorylation of the $M_{\mathrm{r}} 43000$ and 30000 polypeptides, stimulated phosphorylation of a polypeptide of $M_{\mathrm{r}} 18000$ but did not affect other species (Fig. $1 b$ ), is particularly interesting. TFP is a member of the 

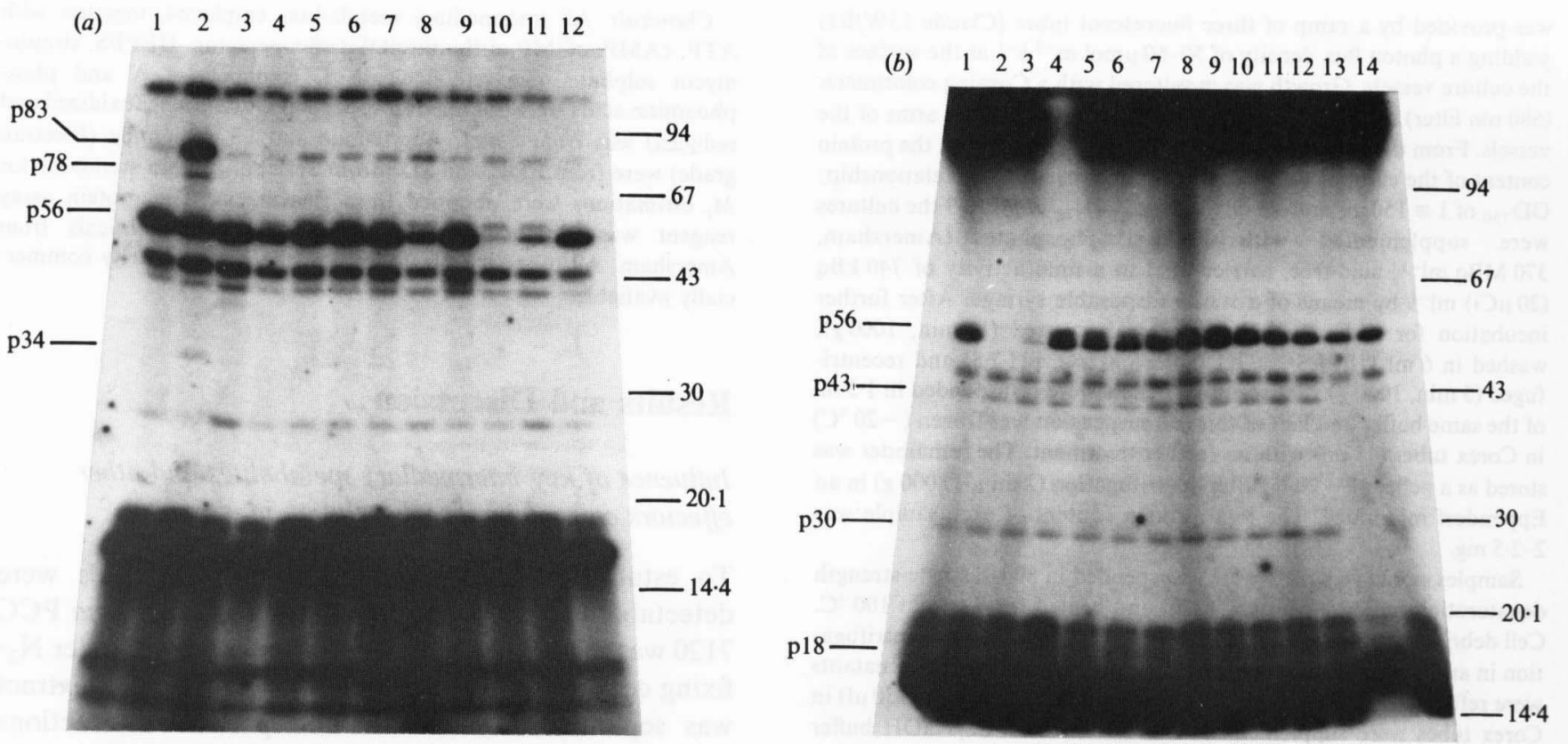

Fig. 1. Effects of intermediary metabolites and other effectors on the phosphopolypeptide patterns of Anabaena PCC 7120, grown under $\mathrm{N}_{2}$-fixing conditions in the presence of glucose and labelled with $\left[\gamma^{32} \mathrm{P}\right] \mathrm{ATP}$ in vitro. The protein kinase reactions were performed on high-speed supernatants ( $10 \mu \mathrm{g}$ protein per assay) of cells disrupted for 4 min with glass beads in HM buffer (see Methods). Additions were as follows. (a) : (1) control, no addition; (2) DTT; (3) potassium ferricyanide; (4) NAD; (5) NADH; (6) NADP; (7) NADPH; (8) ribulose 1,5-bisphosphate; (9) fructose 1-phosphate; (10) fructose 6-phosphate; (11) fructose 1,6bisphosphate; (12) fructose 2,6-bisphosphate. (b): (1) control, no addition; (2) glucose 6-phosphate; (3) ribulose 5-phosphate; (4) 6phosphogluconate; (5) cAMP; (6) cGMP; (7) reduced glutathione; (8) oxidized glutathione; (9) fructose; (10) glucose; (11) glutamine; (12) glutamate; (13) trifluoperazine; (14) $\mathrm{NaHCO}_{3}$. All additions were made to a final concentration of $1 \mathrm{~mm}$ except $\mathrm{NaHCO}_{3}$, which was used at $10 \mathrm{~mm}$. The sizes $\left(10^{-3} \times M_{\mathrm{r}}\right)$ of the major phosphopolypeptides (prefixed ' $\mathrm{p}$ ') and protein standards are shown on the left and right, respectively.

phenothiazines, which in eukaryotes have been shown to act as calmodulin antagonists (see Cheung, 1980). Relatively little is known about the role of calmodulins in prokaryotes, although a calmodulin-like protein has been demonstrated in Escherichia coli (Iwasa et al., 1981) and the ability of TFP to inhibit specific physiological processes such as phosphate uptake by the cyanobacterium Oscillatoria limnetica has been taken as evidence for the occurrence and physiological significance of calmodulin in the latter photosynthetic prokaryote (Kerson et al., 1984). Furthermore, Pettersson \& Bergman (1989) have obtained biochemical and immunological evidence for the presence of calmodulin in three strains of Anabaena and Onec et al. (1990) have reported a calciumbinding protein of $M_{\mathrm{r}} 18000$ in Nostoc PCC 6720, with properties typical of the calmodulin family.

However, it must be recognized that phenothiazines may also exert a variety of effects on prokaryotic cells that do not necessarily involve a calmodulin-like molecule: Peach et al. (1986) have shown that phenothiazines inhibit light-dependent $\mathrm{Ca}^{2+}$ efflux via the $\mathrm{Ca}^{2+} / \mathrm{H}^{+}$ antiport in Chlorobium vinosum and Molnar et al. (1977) demonstrated that these compounds can be used to select for mutants of $E$. coli which lack the Lon protease. If a calmodulin-like mediator were to be involved in the regulation of protein phosphorylation in Anabaena PCC 7120 , then the observed inhibition of phosphorylation of the polypeptides $\mathrm{p} 43$ and $\mathrm{p} 30$ by TFP (which renders calmodulin inactive) in vitro may result from an inhibition of calmodulin-activated kinases, whereas the stimulation by TFP of phosphorylation of the polypeptide 18 could be due to the inactivation of a calmodulinregulated protein phosphatase. In support of the hypothesis that a calmodulin-like molecule may interact with protein kinases or phosphatases in prokaryotes are the results of Londesborough (1986), who showed that brain calmodulin altered the pattern of in vitro phosphorylation in cell-free extracts of Clostridium thermohydrosulfuricum.

Analysis of protein kinase activity in the particulate fraction of cell extracts (Fig. 2) revealed the most pronounced incorporation of label into a polypeptide of $M_{\mathrm{r}} 29000$ (p29). Since phosphorylation of this major phosphopolypeptide in the particulate fraction was inhibited by TFP (data not shown), as was that of a 


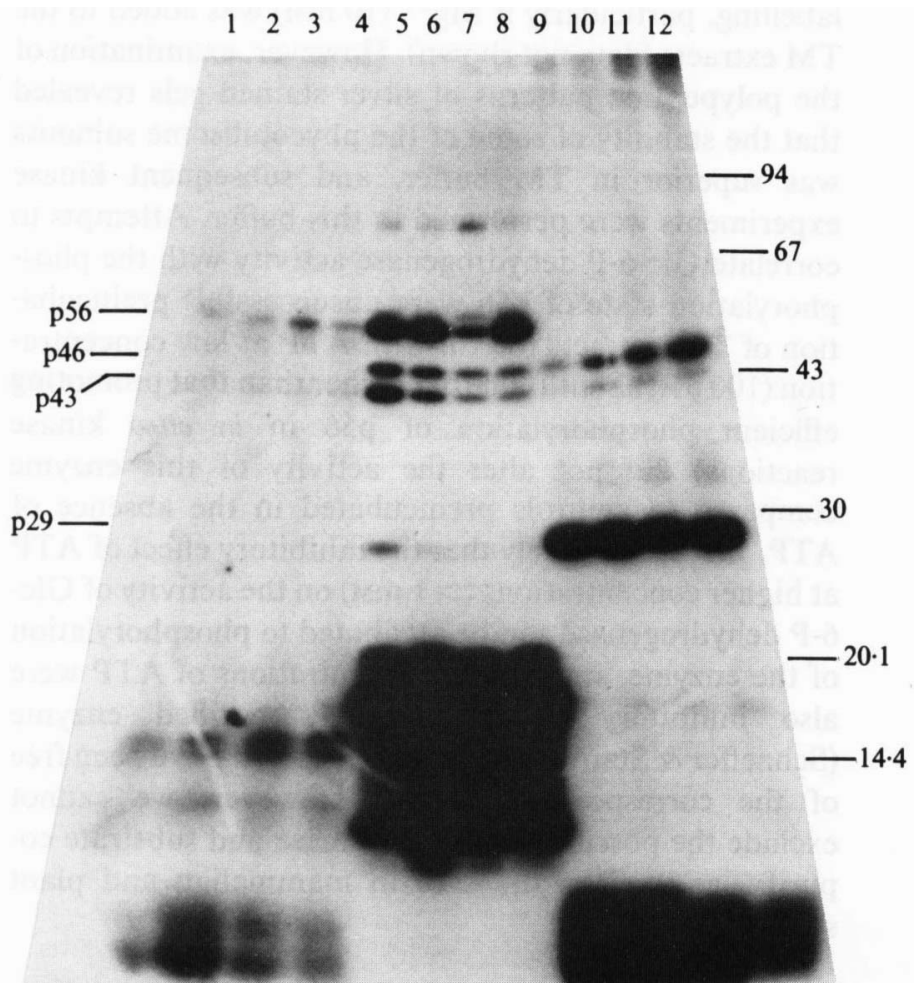

Fig. 2. A comparison of polypeptides labelled in vivo with $\left[{ }^{32} \mathrm{P}\right]$ orthophosphate and in vitro with $\left[\gamma^{32} \mathrm{P}\right] \mathrm{ATP}$. Lanes 1-4, phosphopolypeptides of extracts $(20 \mu \mathrm{g}$ protein) prepared from cells labelled in vivo; lanes 5-12, phosphopolypeptides after in vitro labelling of the soluble fractions (lanes 5-8, $10 \mu \mathrm{g}$ protein) and the particulate fractions (lanes 9-12, $7 \mu \mathrm{g}$ protein) of extracts prepared from cells cultivated in the absence of radioactive phosphate. Growth conditions were as follows. Lanes 1, 5 , 9, absence of combined nitrogen; lanes 2, 6, 10, absence of combined nitrogen but presence of glucose; lanes $3,7,11$, presence of nitrate; lanes $4,8,12$, presence of nitrate and glucose. The sizes $\left(10^{-3} \times M_{\mathrm{r}}\right)$ of the major phosphopolypeptides (prefixed 'p') and protein standards are shown on the left and right, respectively. For details of cell breakage and preparation of extracts, see Methods. minor phosphopolypeptide (p30) of very similar mobility in the soluble fraction (see Fig. $1 b$ ), it is likely that these two polypeptides are identical, their detection in the soluble fraction being due to a slight degree of membrane contamination. In addition, two phosphopolypeptides (p43 and p46) identical in mobility and similar in degree of labelling to two polypeptides phosphorylated in the soluble fraction were detected, suggesting that these might be components of peripheral membrane proteins which tend to dissociate from the membranes during the extraction procedure. Except for TFP, which not only abolished phosphorylation of $\mathrm{p} 29$ but also inhibited that of the peripheral membrane polypeptides $\mathrm{p} 43$ and $\mathrm{p} 46$ (data not shown), none of the metabolites or other potential effectors tested (the same as those employed in the soluble fraction, see Fig. $1 a, b$ ) influenced the phosphopolypeptide pattern of the particulate fraction.

\section{Comparison of polypeptides labelled in vivo and in vitro}

In order to establish whether any of the polypeptides phosphorylated in vitro correspond to species phosphorylated in vivo, we compared the phosphopolypeptide patterns of extracts labelled in vitro at the expense of $[\gamma-$ ${ }^{32}$ P]ATP with those obtained from intact cells labelled for 1.2 generations with [ ${ }^{32} \mathrm{P}$ ]orthophosphate in vivo (Fig. 2). Since growth conditions may influence the extent of protein phosphorylation both in vivo and in vitro, these experiments were performed on cells and extracts derived from cultures grown in the presence and absence of combined nitrogen, with or without exogenous glucose. Preliminary experiments on samples labelled in vivo demonstrated that the phosphorylation patterns obtained upon extracting cell pellets directly in SDS sample buffer were similar to those obtained with cells disrupted with glass beads and treated with DNAase and RNAase prior to denaturation. However, the relatively high background due to contaminating nucleic acids was decreased by the latter treatment, which was therefore chosen for the comparative analysis shown in Fig. 2.

The results show clearly that a number of phosphopolypeptides labelled in vivo correspond in mobility on SDS-PAGE to those obtained with extracts labelled in vitro (Fig. 2). One of the more prominent phosphopolypeptides, p56, was more strongly labelled in vivo in cells grown photoautotrophically in the presence of nitrate than in those grown under $\mathrm{N}_{2}$-fixing conditions in either the presence or absence of glucose. However, the addition of glucose to cells growing in the presence of nitrate abolished this stimulation (Fig. 2). Interestingly, in vitro kinase assays of soluble fractions prepared from cells grown under equivalent conditions but in the absence of $\left[{ }^{32} \mathrm{P}\right]$ orthophosphate gave the opposite pattern of phosphorylation of $\mathrm{p} 56$ to that observed in vivo (Fig. 2). These results suggest that: (1) the phosphorylation state of p56 in vivo is regulated by the supply of 
combined nitrogen; (2) exogenous glucose may alter the control of phosphorylation exerted by the source of nitrogen; and (3) the degree of labelling of this polypeptide in vitro is inversely related to its phosphorylation state in vivo (i.e. low levels of in vitro protein phosphorylation are indicative of extensive in vivo phosphorylation). Although no attempt was made in this study to discriminate between protein phosphorylation in vegetative cells and heterocysts of Anabaena PCC 7120 , p56 cannot be specifically associated with the heterocysts, since differentiation of this cell type is repressed in the presence of nitrate, irrespective of the presence or absence of glucose.

Labelling of the particulate fraction of extracts in vitro revealed that incorporation into $\mathrm{p} 29$ was not influenced by the growth conditions of the cells (Fig. 2, lanes 9-12) whereas some differences were observed for $\mathrm{p} 46$ and $\mathrm{p} 43$, assumed to be polypeptides loosely associated with membranes (see above). The presence of nitrate seemed to favour the association of $\mathrm{p} 46$ with the particulate fraction, whereas in extracts from cultures grown in the absence of nitrate this polypeptide partitioned predominantly with the soluble protein fraction. However, the sum of labelling of $\mathrm{p} 46$ in the two fractions seems to exclude major differences in the total degree of labelling of this polypeptide. In contrast, p43, occurring mainly in the soluble protein fraction, was more strongly labelled in extracts from cells grown in the absence than in the presence of nitrate, even after taking into account the slightly stronger incorporation into $\mathrm{p} 43$ in the particulate fraction prepared from cells grown in the presence of nitrate (Fig. 2, lanes 5-12).

Since the gel comparing in vivo and in vitro labelling was treated after electrophoresis with hot trichloroacetic acid to hydrolyse remaining nucleic acids, the acid-stable phosphopolypeptides (Fig. 2) must contain monoester linkages rather than phosphoramidates or acyl phosphates, whose bonds are labile under such conditions (Manai \& Cozzone, 1982). This was confirmed for p56, whose phosphoamino acid was identified as phosphoserine (data not shown).

Attempts to correlate phosphorylation of polypeptide p56 with changes in Glc-6-P dehydrogenase activity

The $M_{\mathrm{r}}$ of about 56000 (Cossar et al., 1984), and the regulatory effects of Glc-6-P and $\mathrm{Ru}-5-\mathrm{P}$ on the in vitro phosphorylation of p56 (see above), suggested that p56 could possibly be a subunit of Glc-6-P dehydrogenase. Extracts were therefore prepared in TM buffer, optimal for measuring the activity of this enzyme (Schaeffer \& Stanier, 1978). A comparison of the in vitro labelling of extracts prepared in HM or TM buffer showed only minor differences in the overall pattern and degree of labelling, particularly if $\mathrm{Mg}^{2+}(10 \mathrm{~mm})$ was added to the TM extracts (data not shown). However, examination of the polypeptide patterns of silver-stained gels revealed that the stability of some of the phycobilisome subunits was superior in TM buffer, and subsequent kinase experiments were performed in this buffer. Attempts to correlate Glc-6-P dehydrogenase activity with the phosphorylation state of $\mathrm{p} 56$ were unsuccessful: preincubation of TM extracts for $1 \mathrm{~h}$ with ATP at low concentration $(100 \mu \mathrm{M}$, about 1000 -fold higher than that promoting efficient phosphorylation of $\mathrm{p} 56$ in in vitro kinase reactions) did not alter the activity of this enzyme compared to controls preincubated in the absence of ATP. It seems unlikely that the inhibitory effect of ATP at higher concentrations $(>1 \mathrm{~mm})$ on the activity of Glc6-P dehydrogenase can be attributed to phosphorylation of the enzyme, since these concentrations of ATP were also inhibitory to the partially purified enzyme (Schaeffer \& Stanier, 1978), which should have been free of the corresponding kinase. However, we cannot exclude the possibility that the kinase and substrate copurify, as is often the case in mammalian and plant systems.

\section{Effect of $\mathrm{Mg}^{2+}$ on protein phosphorylation}

In order to establish the effect of $\mathrm{Mg}^{2+}$ on the pattern of protein phosphorylation, cell-free extracts in TM buffer were dialysed against the same buffer. Protein kinase activities were then assayed after the addition of $\mathrm{MgCl}_{2}$ at different concentrations (Fig. 3). It is clear that the maximum incorporation of label into $\mathrm{p} 56$ required $\mathrm{Mg}^{2+}$ concentrations greater than $100 \mu \mathrm{M}$. However, the most striking observation on these dialysed extracts was the detection of a polypeptide (p16) of $M_{\mathrm{r}} 16000$ whose phosphorylation was inhibited by high concentrations $(>1 \mathrm{mM})$ of $\mathrm{Mg}^{2+}$. Since the presence of trace amounts of $\mathrm{Mg}^{2+}$ after dialysis could not be excluded, kinase reactions were also performed in the presence of EDTA (1-2 mM). Under these conditions pl6 was strongly phosphorylated (data not shown), even in TM extracts not subjected to dialysis.

To determine whether high concentrations of $\mathrm{Mg}^{2+}$ exerted an effect on the phosphorylation of p16 by inhibiting the corresponding kinase or by activating a phosphatase, this cation ( $10 \mathrm{~mm}$ ) was added either at the start of the kinase reaction or after $30 \mathrm{~min}$ of the $1 \mathrm{~h}$ incubation period. If $\mathrm{Mg}^{2+}$ at this concentration were to inhibit the kinase, one would expect that its addition after $30 \mathrm{~min}$ should lead to about $50 \%$ of incorporation of label compared to that observed in kinase reactions incubated for the total incubation period in the absence of $\mathrm{Mg}^{2+}$. In contrast, if high concentrations of $\mathbf{M g}^{2+}$ were to stimulate a phosphatase, its addition after $30 \mathrm{~min}$ 


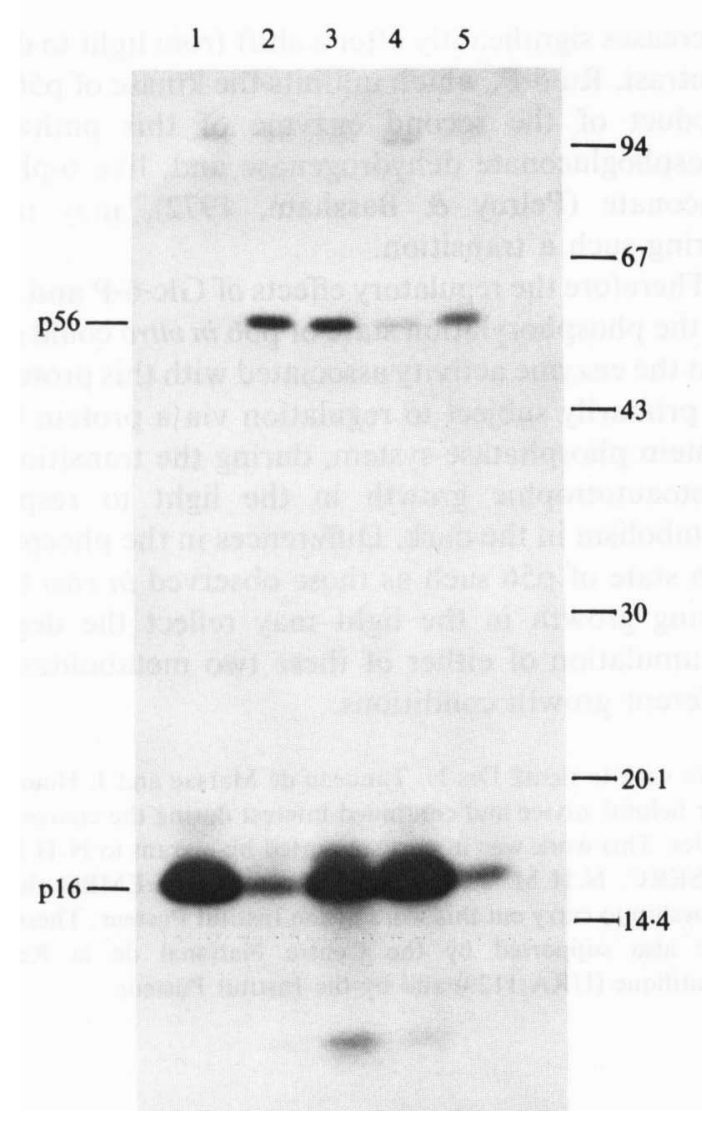

Fig. 3. Effect of $\mathrm{Mg}^{2+}$ concentration on protein phosphorylation in vitro of the soluble fraction ( $20 \mu \mathrm{g}$ protein) of extracts prepared in TM buffer from cells grown under $\mathrm{N}_{2}$-fixing conditions in the presence of glucose. The kinase reactions were performed on extracts extensively dialysed against the same buffer and after the addition of the following concentrations of $\mathrm{MgCl}_{2}$; (1) no addition; (2) $10 \mathrm{mM}$; (3) $1 \mathrm{mM}$; (4) $0.1 \mathrm{~mm}$. The last lane (5) shows the result of labelling for $30 \mathrm{~min}$ in the absence of $\mathrm{Mg}^{2+}$, followed by further incubation (30 min) in the presence of $\mathrm{Mg}^{2+}(10 \mathrm{mM})$. The sizes $\left(10^{-3} \times M_{\mathrm{r}}\right)$ of the major phosphopolypeptides (prefixed 'p') and protein standards are shown on the left and right, respectively.

should lead to a much more pronounced decrease of incorporation of label. Since the latter was observed (Fig. 3, compare lanes 1 and 5), the results suggest that $\mathrm{Mg}^{2+}$ activates a phosphatase apparently specific for $\mathrm{p} 16$. This conclusion is based on two assumptions: (1) that incorporation was linear over the $1 \mathrm{~h}$ period and (2) that the phosphatase apparently specific for pl6 has low activity at concentrations of $\mathrm{Mg}^{2+}$ below $1 \mathrm{mM}$ and thus ${ }^{32} \mathrm{P}$ turnover is low. Although the linearity of the kinase reaction in these experiments was not directly examined by the addition of excess unlabelled ATP at different time intervals, the effect of $\mathrm{Mg}^{2+}$ on the phosphorylation of p56 indicates such a response: if $\mathrm{Mg}^{2+}(10 \mathrm{mM})$, required for efficient phosphorylation of $\mathrm{p} 56$, was added at time zero of the kinase reaction the degree of labelling was about twice as strong as that observed following addition at the midpoint (30 $\mathrm{min}$ ) of the reaction (Fig. 3, compare lanes 2 and 5), indicating that ATP could not have become limiting during the reaction. Furthermore, turnover of the phosphate group(s) in p16 at low concentrations of $\mathrm{Mg}^{2+}$ must be low or zero since the extensive net labelling of p16 observed under these conditions would otherwise be difficult to explain.

The phosphoamino acid of pl6 was identified as phosphoserine (data not shown).

It should be noted that the proteins composed of the polypeptides p56 and p16, together with their kinases and phosphatases, are extremely stable: kinase reactions performed in TM extracts which were previously dialysed and stored at $0-4{ }^{\circ} \mathrm{C}$ for several weeks without addition of protease inhibitors showed unaltered phosphorylation properties (i.e. degree of labelling and response to regulation by $\mathrm{Mg}^{2+}$ ) (data not shown).

\section{Regulation of phosphorylation of polypeptide p56 by Glc-6-P and $R u-5-P$}

In order to determine whether Glc-6-P and Ru-5-P affected the phosphorylation of p56 (see Fig. $1 b$ ) by inhibiting a kinase or activating a phosphatase, these metabolites were added either individually or together $30 \mathrm{~min}$ after the start of the kinase reactions (which were performed for $1 \mathrm{~h}$ ). The controls received either water, excess unlabelled ATP or unlabelled ATP in combination with one or both of the metabolites. Addition of an excess of unlabelled ATP to the control after $30 \mathrm{~min}$ of incubation led to only a slight reduction in the expected incorporation, which should be $50 \%$ of that observed after $1 \mathrm{~h}$ of incubation without added ATP (Fig. 4, compare lanes 1 and 5), indicating both linearity of the kinase reaction and low phosphatase activity.

In contrast, it is clear (Fig. 4) that Glc-6-P alone or in combination with $\mathrm{Ru}-5-\mathrm{P}$, both with and without unlabelled ATP, decreased the labelling of p56 by far more than $50 \%$, suggesting that Glc-6-P stimulates the activity of a phosphatase, whereas the patterns of phosphorylation of p56 observed after addition of Ru-5$\mathrm{P}$ alone or in combination with unlabelled ATP suggest that $\mathrm{Ru}-5-\mathrm{P}$ inhibits a protein kinase.

Inorganic phosphate at concentrations of $10-50 \mathrm{mM}$ stimulated phosphorylation of p56 and seemed to exert its effect by inhibiting the phosphatase (data not shown).

One of the major metabolic transitions for a cyanobacterial cell in the natural habitat is that from photoautotrophic growth in the light to heterotrophic respiratory metabolism in the dark. This is characterized by a rapid reduction in the activities of the enzymes of the Calvin cycle and a concomitant increase in the activities of the 


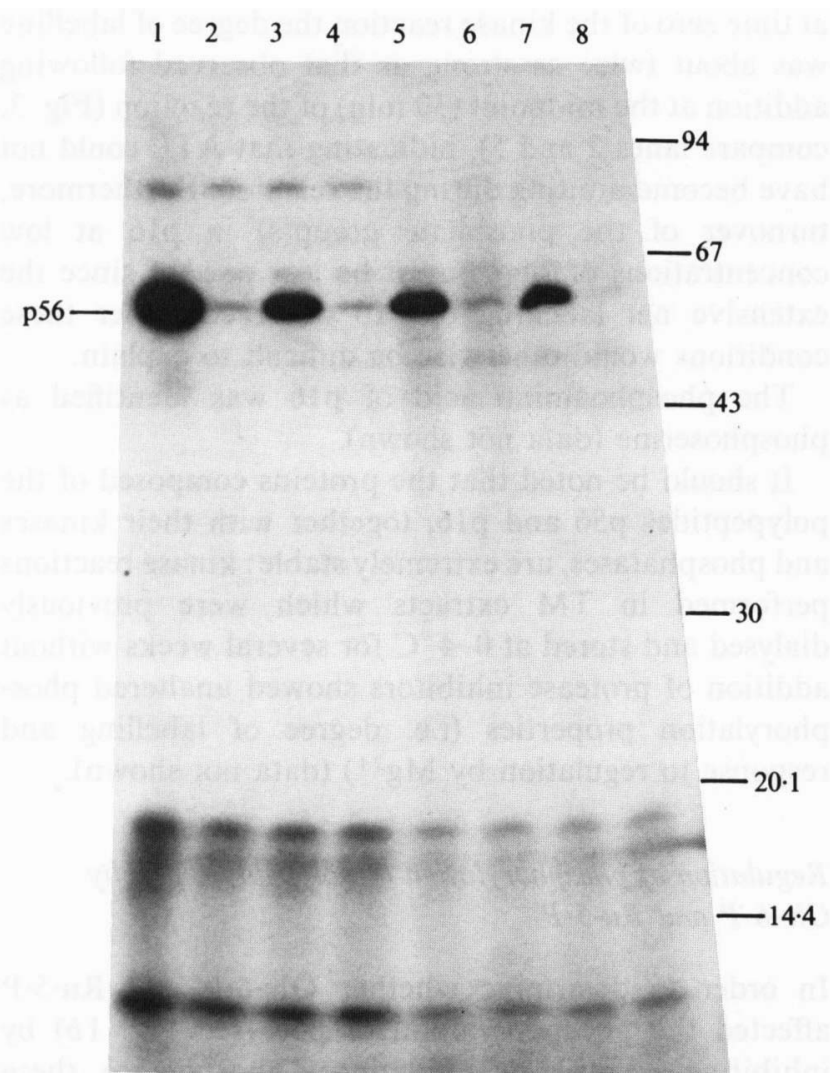

Fig. 4. Differential effects of Glc-6-P and Ru-5-P on the phosphorylation state of $\mathrm{p} 56$. Samples $(20 \mu \mathrm{g}$ protein) of the soluble fraction of a cell-free extract (in TM buffer) prepared from cells grown under $\mathrm{N}_{2}$-fixing conditions in the presence of glucose were incubated with [ $\left.\gamma^{-32} \mathrm{P}\right] \mathrm{ATP}$ for $30 \mathrm{~min}$ prior to the addition of Glc-6-P (1 mM), Ru-5-P (1 mM) or ATP $(500 \mu \mathrm{M})$, either individually or in combinations. The reactions were terminated after further incubation for $30 \mathrm{~min}$. Additions were as follows: (1) $\mathrm{H}_{2} \mathrm{O}$, control ; (2) Glc-6-P, (3) Ru-5-P ; (4) Glc-6-P and Ru-5-P; (5) ATP; (6) Glc-6-P and ATP; (7) Ru-5-P and ATP; (8) Glc-6-P, Ru-5-P and ATP. The sizes $\left(10^{-3} \times M_{\mathrm{r}}\right)$ of the major phosphopolypeptides (prefixed ' $p$ ') and protein standards are shown on the left and right, respectively.

enzymes of the pentose phosphate pathway, permitting the oxidation of glucose from storage polysaccharides (see Smith, 1982). Phosphorylation of p56 was markedly inhibited by Fru-1,6- $\mathrm{P}_{2}$, Fru-6-P, Glc-6-P and Ru-5-P. This multiplicity of effectors can be simplified by considering their possible interconversion in cell-free extracts. It seems likely that both Fru-1,6-P $\mathbf{P}_{2}$ and Fru-6-P may exert their regulatory effect on the phosphorylation of p56 as the result of conversion to Glc-6-P via the activities of fructose-1,6-bisphosphatase and hexose-6phosphate isomerase, which have been shown to be active in cyanobacterial cell-free extracts (see Smith, 1982). Glc-6-P, which stimulates the phosphatase of $p 56$, is the substrate of Glc-6-P dehydrogenase, the first enzyme of the oxidative pentose phosphate pathway, and decreases significantly after a shift from light to dark. In contrast, Ru-5-P, which inhibits the kinase of $\mathrm{p} 56$, is the product of the second enzyme of this pathway, 6phosphogluconate dehydrogenase and, like 6-phosphogluconate (Pelroy \& Bassham, 1972), may increase during such a transition.

Therefore the regulatory effects of Glc-6-P and Ru-5-P on the phosphorylation state of p56 in vitro could suggest that the enzyme activity associated with this protein may be primarily subject to regulation via a protein kinase/ protein phosphatase system, during the transition from photoautotrophic growth in the light to respiratory metabolism in the dark. Differences in the phosphorylation state of p56 such as those observed in vivo (Fig. 2) during growth in the light may reflect the degree of accumulation of either of these two metabolites under different growth conditions.

We wish to thank Drs N. Tandeau de Marsac and J. Houmard for their helpful advice and continued interest during the course of these studies. This work was in part supported by a grant to N.H.M. from the SERC. N.H.M. acknowledges receipt of an EMBO short-term fellowship to carry out this work at the Institut Pasteur. These studies were also supported by the Centre National de la Recherche Scientifique (URA 1129) and by the Institut Pasteur.

\section{References}

Allen, J. F., Sanders, C. E. \& Holmes, N. G. (1985). Correlation of membrane protein phosphorylation with excitation energy distribution in the cyanobacterium Synechococcus 6301. FEBS Letters 193, 271-275.

BRADFORD, M. (1976). A rapid and sensitive method for the quantitation of microgram quantities of protein utilizing the principle of protein-dye binding. Analytical Biochemistry 72, 248254.

Cheung, W. Y. (1980). Calmodulin plays a pivotal role in cellular regulation. Science 207, 19-27.

Cossar, J. D., Rowell, P. \& Stewart, W. D. P. (1984). Thioredoxin as a modulator of glucose-6-phosphate dehydrogenase in a $\mathrm{N}_{2}$-fixing cyanobacterium. Journal of General Microbiology 130, 991-998.

Cozzone, A. J. (1988). Protein phosphorylation in prokaryotes. Annual Review of Microbiology 42, 97-125.

Crawford, N. A., Yee, B. C., Droux, M., Carlson, D. E. \& Buchanan, B. B. (1988). Ferredoxin/thioredoxin system. Methods in Enzymology 167, 415-427.

Dadssi, M. \& Cozzone, A. J. (1985). Cyclic AMP independence of Escherichia coli protein phosphorylation. FEBS Letters 186, 187-190.

Holuigue, L., Lucero, H. A. \& Vallejos, R. H. (1985). Protein phosphorylation in the photosynthetic bacterium Rhodospirillum rubrum. FEBS Letters 181, 103-108.

Iwasa, Y., Yonemitsu, K., Matsui, K., Fukunaga, K. \& Miyamoto, E. (1981). Calmodulin-like activity in the soluble fraction of Escherichia coli. Biochemical and Biophysical Research Communications 98, 656-660.

Kerson, G. W., Miernyk, J. A. \& Budd, K. (1984). Evidence for the occurrence of, and possible physiological role for, cyanobacterial calmodulin. Plant Physiology 75, 222-224.

LACHANCE, M.-A. (1981). Genetic relatedness of heterocystous cyanobacteria by deoxyribonucleic acid-deoxyribonucleic acid reassociation. International Journal of Systematic Bacteriology 31, 139-147. 
LAEMmLI, U. K. (1970). Cleavage of structural proteins during the assembly of the head of bacteriophage $\mathrm{T}_{4}$. Nature, London 227, 680685.

LONDESBOROUGH, J. (1986). Phosphorylation of proteins in Clostridium thermohydrosulfuricum. Journal of Bacteriology 165, 595-601.

MANAI, M. \& Cozzone, A. J. (1982). Endogenous protein phosphorylation in Escherichia coli extracts. Biochemical and Biophysical Research Communications 107, 981-988

Molnar, J., Holland, I. B. \& Mandi, Y. (1977). Selection of lon mutants in Escherichia coli by treatment with phenothiazines. Genetic Research Communications 30, 13-30.

ONeC, L. A., LeA, P. J. \& SMith, R. J. (1990). Cyanobacterial calmodulin. In Proceedings of the First European Workshop on the Molecular Biology of Cyanobacteria, p. 91. Edited by N. Tandeau de Marsac, J. Houmard, F. Joset, G. A. Codd \& G. Schmetterer.

Peach, C. R., СobB, A. D., Smith, J. A. \& KnafF, D. B. (1986) Evidence for two calcium transport systems in the photosynthetic bacterium Chromatium vinosum. FEBS Letters 200, 309-313.

Pelroy, R. A. \& Bassham, J. A. (1972). Photosynthetic and dark carbon metabolism in unicellular blue-green algae. Archiv für Mikrobiologie 86, 25-38.

Pettersson, A. \& Bergman, B. (1989). Calmodulin in heterocystous cyanobacteria: biochemical and immunological evidence. FEMS Microbiology Letters 60, 95-100.

Rippka, R., Deruelles, J., Waterbury, J. B., Herdman, M. \& Stanier, R. Y. (1979). Generic assignments, strain histories and properties of pure cultures of cyanobacteria. Journal of General Microbiology 111, 1-61.

RIPPKa, R., Waterbury, J. B. \& Stanier, R. Y. (1981). Isolation and purification of cyanobacteria: some general principles. In The Prokaryotes, pp. 212-220. Edited by M. P. Starr, H. Stolp, H. G. Trüper, A. Balows \& H. G. Schlegel. Berlin, Heidelberg \& New York: Springer-Verlag.
Rowell, P., Darling, A. J. \& Stewart, W. D. P. (1988). Thioredoxin system. Methods in Enzymology 167, 410-415.

Sanders, C. E., Melis, A. \& Allen, J. F. (1989). In vivo phosphorylation of proteins in the cyanobacterium Synechococcus 6301 after chromatic acclimation to photosystem I or photosystem II light. Biochimica et Biophysica Acta 976, 168-172.

SChAEFFER, F. \& Stanier, R. Y. (1978). Glucose-6-phosphate dehydrogenase of Anabaena sp. Kinetic and molecular properties. Archives of Microbiology 116, 9-19.

Schuster, G., OWens, G. C., Cohen, Y.\& Ohad, I. (1984). Thylakoid polypeptide composition and light-independent phosphorylation of the chlorophyll $a, b$ protein in Prochloron, a prokaryote exhibiting oxygenic photosynthesis. Biochimica et Biophysica Acta 767, 596605 .

SMITH, A. J. (1982). Modes of cyanobacterial carbon metabolism. In The Biology of the Cyanobacteria, pp. 47-86. Edited by N. G. Carr \& B. A. Whitton. Oxford: Blackwell Scientific Publications.

SKORKo, R. (1984). Protein phosphorylation in the archaebacterium Sulfolobus acidocaldarius. European Journal of Biochemistry 145, 617 622.

Stock, J. B., Ninfa, A. J. \& Stock, A. M. (1989). Protein phosphorylation and regulation of adaptive responses in bacteria. Microbiological Reviews 53, 450-490.

Tandeau DE Marsac, N. \& Houmard, J. (1988). Complementary chromatic adaptation: physiological conditions and action spectra. Methods in Enzymology 167, 318-328.

TURner, A. M. \& MANN, N. H. (1986). Protein phosphorylation in Rhodomicrobium vanielii. Journal of General Microbiology 132, 3433 3440.

Wray, W., Boulikas, T., Wray, V. P. \& Hancock, R. (1981). Silver staining of proteins in polyacrylamide gels. Analytical Biochemistry 118, 197-203. 